INDONESIAN JOURNAL OF

Clinical Pathology and Medical Laboratory

Majalah Patologi Klinik Indonesia dan Laboratorium Medik

\begin{tabular}{|c|c|c|c|c|c|}
\hline $\begin{array}{c}\text { IJCP \& ML } \\
\begin{array}{c}\text { (Maj. Pat. Klin. } \\
\text { Indonesia \& Lab. Med.) }\end{array}\end{array}$ & Vol. 17 & No. 3 & Hal. 127-177 & $\begin{array}{c}\text { Surabaya } \\
\text { Juli 2011 }\end{array}$ & $\begin{array}{c}\text { ISSN } \\
0854-4263\end{array}$ \\
\hline
\end{tabular}

Diterbitkan oleh Perhimpunan Dokter Spesialis Patologi Klinik Indonesia

Published by Indonesian Association of Clinical Pathologists

Terakreditasi No: 43/DIKTI/Kep/2008, Tanggal 8 Juli 2008 


\section{INDONESIAN JOURNAL OF \\ CLINICAL PATHOLOGY AND MEDICAL LABORATORY \\ Majalah Patologi Klinik Indonesia dan Laboratorium Medik}

\section{DAFTAR ISI}

\section{PENELITIAN}

Creatine Kinase Myocardial Band, Myeloperoxidase, Matrix Metalloproteinase- 9 dan Troponin T Pada IMA

(The Creatine Kinase Myocardial Band, Myeloperoxidase, Matrix Metalloproteinase-9 Activities and Troponin $T$ in Myocardial Infarction)

IA Hutagalung, I Patellongi, R Pakasi, M Arif, AA Mappahya, Hardjoeno

D-Dimer Penderita Sindrom Koroner Akut dan Stenosis

(D-Dimer in Acute Coronary Syndrome and Stenosis)

Birhasani, Lisyani BS, Ria T

Uji Hematologi Pasien Terduga Demam Berdarah Dengue Indikasi Rawat Inap

(Hematology Test of Dengue Hemorrhagic Fever on Suspected Patients Indicated for Hospitalization) Juranah, Darwati Muhadi, Mansyur Arif, Burhanuddin Bahar .

Imunokimiawi PGE2 Usus Ileum yang Kekurangan Energi Protein

(Immunohistochemistry of PGE2 Ileum Intestine Protein Energy Deficiency)

R. Heru Prasetyo

Gamma-glutamyltransferase dan Apolipoprotein B dengan Sindroma Metabolik

(Gamma-glutamyltransferase and Apolipoprotein B with the Metabolic Syndrome)

Tahono, M.I. Diah Pramudianti.

146-150

Umbi Ubi Jalar Ungu Bali (Ipomoea batatas) di Transaminase Serum, Malondialdehide Hepar dan Alkohol Kronis

(Balinese Purple Sweet Potato (Ipomoea batatas L) on SGOT, SGPT, MDA level and Chronic Alcohol) I Wayan Putu Sutirta-Yasa, I Made Jawi, Ida Bagus Ngurah, Anak Agung Ngurah Subawa.

Leukosit Infeksi Bakteri Sistemik

(Leucocyte in Systemic Bacterial Infections)

Meita Hendrianingtyas, MI. Tjahjati DM

Meningitis Tuberculosis

(Meningitis Tuberculosis)

Silvia Rachmayati, Ida Parwati, A Rizal, D Oktavia

Platelet Aggregation In Acute Coronary Syndrome

(Aggregasi Trombosit di Sindroma Koroner Akut)

Sulianty, Adi K Aman..

TELAAH PUSTAKA

Pemetaan Epitop dan Aplikasi Klinisnya

(Epitope Mapping and It's Clinical Aplication)

Jusak Nugraha.

LAPORAN KASUS

Infeksi Virus Rabies di Anak-anak

(Rabies Virus Infection in Children)

A.A.N. Subawa, DGD. Dharma Santhi, A.A Raka Sudewi, IWP. Sutirta Yasa 


\title{
IMUNOKIMIAWI PGE2 USUS ILEUM YANG KEKURANGAN ENERGI PROTEIN
}

\author{
(Immunohistochemistry of PGE2 Ileum Intestine Protein Energy Deficiency)
}

\author{
R. Heru Prasetyo
}

\begin{abstract}
Diarrhoeal disease mortality which suffered by children less than five years due to protein energy deficiency is increased significantly. The pathological mechanisms are not known in detail yet. The objective of this research was able to explain the intestine motility in protein energy deficiency of mice Balb/c. Hormonal mechanism that regulates the intestine motility is roled by prostaglandine $E_{2}$ hormone $\left(P G E_{2}\right)$. The observed variable was the immunity component of PGE2. The measurement was performed using immunohistochemistry method with monoclonal antibody against PGE2 to the ileum mice tissue. The result of this study showed that protein energy deficiency mice had much reduced PGE2 (reduction from 1492 to 145, $p=0.000$ ). In conclusion, the marked decrease of ileum PGE2 will decrease intestine motility and it may be one cause of the high diarrhoeal mortality due to protein energy deficiency.
\end{abstract}

Key words: PGE2, immunohistochemistry, ileum, protein energy deficiency

\begin{abstract}
ABSTRAK
Angka kematian anak di bawah umur lima tahun karena penyakit diare meningkat secara bermakna akibat kekurangan asupan protein. Mekanisme patologisnya tidak diketahui secara rinci. Tujuan penelitian ini adalah untuk dapat menjelaskan daya gerak (motilitas) usus di mencit Balb/c kurang asupan protein. Mekanisme hormonal yang mengatur motilitas usus diperankan oleh hormon prostaglandin $\mathrm{E}_{2}\left(\mathrm{PGE}_{2}\right)$. Variabel yang diamati adalah komponen imunitas PGE2. Pengukuran dilakukan dengan cara imunohistokimiawi menggunakan antibodi monoklon terhadap PGE2 di jaringan ujung usus halus (ileum) mencit. Hasil telitian ini menunjukkan bahwa mencit kekurangan energi protein, karena banyak mengalami pengurangan PGE2 (berkurang dari 1492 menjadi 145, $\mathrm{p}=0,000$ ). Sebagai simpulan, penurunan PGE2 ileum dapat menurunkan motilitas usus dan dapat menjadi salah satu penyebab ketinggian angka kematian karena diare akibat kekurangan asupan protein.
\end{abstract}

Kata kunci: $\mathrm{PGE}_{2}$, imunohistokimiawi, ileum, kekurangan energi protein

\section{PENDAHULUAN}

Sampai saat ini kurang gizi masih menjadi masalah kesehatan di Indonesia, yaitu jumlah penyakit tertentu dengan kekurangan enerji protein yang sejak tahun 2000 di Indonesia menunjukkan peningkatan. Hasil memantau Direktorat Gizi Masyarakat Kementerian Kesehatan, menunjukkan bahwa Jawa Timur sejak tahun 2005 termasuk dalam kelompok sepuluh provinsi dengan kasus kekurangan enerji protein tertinggi. Pada tahun 2009 Jawa Timur menduduki posisi teratas kasus kekurangan enerji protein nasional. Kekurangan enerji protein berkaitan dengan peningkatan kejadian penyakit infeksi. Kematian balita kurang gizi di Indonesia jumlahnya lebih dari 50\% disebabkan karena kurang asupan protein, dan yang menjadi penyebab kematian balita kurang gizi adalah peningkatan angka kematian akibat penyakit diare. ${ }^{1}$

Dalam kejadian diare seringkali berkaitan dengan hipermotilitas usus. ${ }^{2}$ Namun, dalam kekurangan asupan protein peran motilitas usus dalam mekanisme patologik kejadian diare belum terungkap dengan jelas. Dalam dasarnya motilitas usus diatur melalui mekanisme hormon dan saraf. ${ }^{1}$ Di usus bagian atas mekanisme hormon lebih berperan, sedangkan di usus bagian bawah mekanisme saraf lebih menonjol. ${ }^{3}$ Mekanisme hormon yang mengatur motilitas usus diperankan oleh hormon prostaglandin $\mathrm{E}_{2}\left(\mathrm{PGE}_{2}\right){ }^{4}$ $\mathrm{PGE}_{2}$ dihasilkan oleh sel imun aktif seperti sel epitel, makrofag, sel mast, dan limfosit, melalui sifat oksitosiknya memengaruhi otot polos saluran cerna terutama kemampuan untuk meningkatkan motilitas atau gerak peristaltik usus. ${ }^{5-7}$ Karena itu perubahan motilitas usus secara tidak langsung diketahui melalui perubahan penunjukan $\mathrm{PGE}_{2}$ mukosa usus. Dalam penelitian ini akan dikaji pengaruh kekurangan asupan protein terhadap kandungan PGE2 selaput lendir (mukosa) usus dengan menggunakan teknik imunohistokimiawi. 


\section{METODE}

\section{Hewan Coba}

Hewan coba yang digunakan dalam kajian ini adalah mencit Balb/c jantan, berumur 8-10 minggu, dengan bobot 20-30 gram yang diperoleh dari Unit Pengembangan Hewan Percobaan Pusvetma Surabaya. Hewan coba disesuaikan keadaannya (diadaptasikan) selama 7 hari di Kandang Hewan Coba Departemen Biokimia Fakultas Kedokteran Unair. Kemudian dikelompokkan menjadi 2 (dua) kelompok, yaitu kelompok kurang energi protein (KEP) dan kelompok non KEP. Kelompok non KEP diberi pakan baku (standar) berupa gentel (pelet) sebanyak 15-20 gr diberikan sekali sehari dan air minum berupa air PDAM diberikan dengan cara tetes. Kelompok KEP dipuasakan dengan jalan tidak diberi pakan selama 72 jam, hanya diberi minum setiap 8 jam melalui sonde. ${ }^{8-9}$ Semua hewan coba harus tampak sehat sebelum dimatikan. Penelitian dengan menggunakan hewan coba mencit ini telah melalui uji kelayakan perlakuan (ethical clearance) oleh Komite Etik Fakultas Kedokteran Hewan Universitas Airlangga.

\section{Pengecatan Hematoxylin Eosin (HE) dan Imunohistokimiawi}

Setelah mencit dikorbankan, diambil jaringan usus sepanjang $1,5 \mathrm{~cm}$, direndam di dalam larutan formalin PZ 10\% selama 10 jam, kemudian dibuat balok parafin. Selanjutnya balok parafin tersebut disayat secara berderet untuk kemudian dari masing-masing balok dibuat 2 (dua) sediaan di gelas objek. Satu sediaan dicat dengan HE untuk menentukan gambaran histologis mukosa usus, sedangkan sediaan yang lain dicat dengan teknik imunohistokimiawi menggunakan antibodi monoklon di PGE2. Pembacaan dilakukan dengan menggunakan mikroskop cahaya pembesaran $400 \times .{ }^{10}$ Secara positif imunohistokimiawi PGE2 ditunjukkan dengan adanya bentukan yang berwarna coklat.

\section{Analisis Statistik}

Pada penelitian ini data yang didapat diuji dengan uji kebersamaan dan uji kenormalan dilanjutkan dengan analisis Anova.

\section{HASIL DAN PEMBAHASAN}

Hasil periksaan histologis sayatan melintang ileum mencit yang berkekurangan asupan protein (KEP) yang dicat HE menunjukkan ada kerusakan epitel dan tonjolan selaput melisut/atropi vilus (Gambar 1).

Hasil mengecat dengan teknik imunohistokimiawi memperlihatkan penurunan penunjukkan $\mathrm{PGE}_{2}$ yang

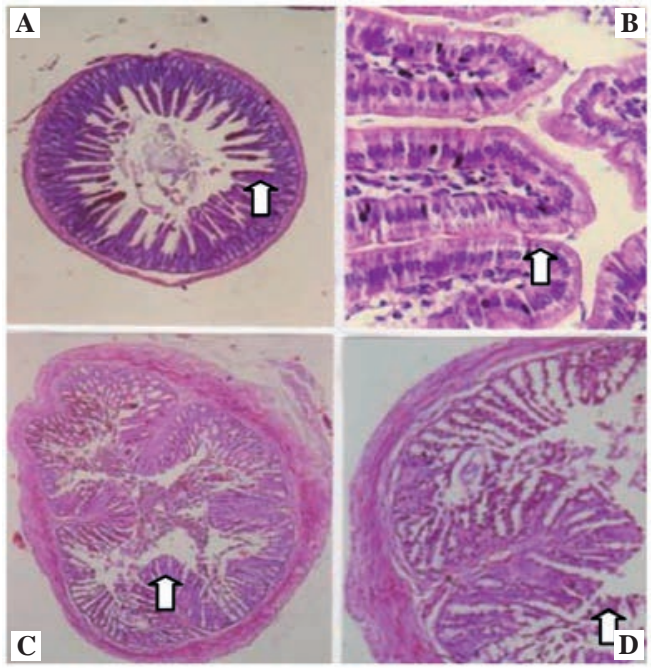

Gambar 1. Sayatan melintang ileum mencit dengan pengecatan HE.

A dan B dari ileum mencit non KEP, C dan D dari ileum mencit KEP.

A dan C pembesaran $40 \times$, sedangkan B dan D pembesaran $400 \times$.
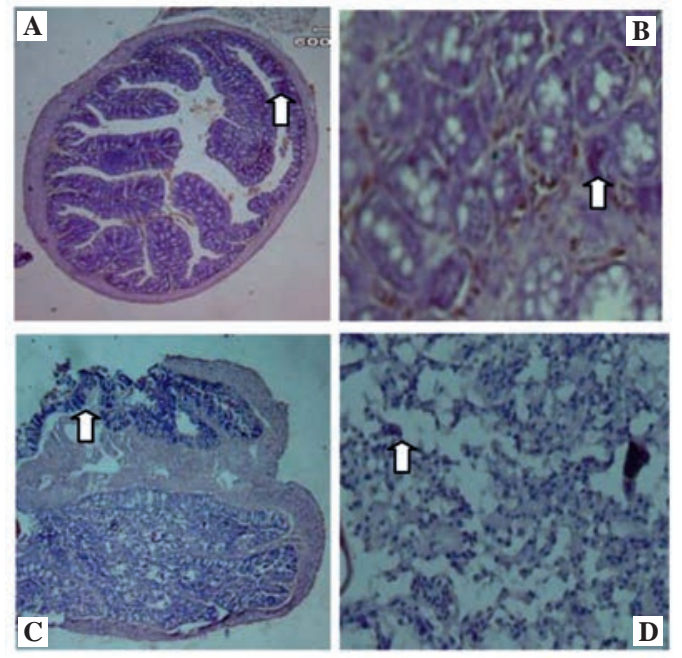

Gambar 2. Sayatan melintang jaringan ileum mencit dicat dengan teknik imunohistokimiawi.

A dan $C$ pembesaran $40 \times$, B dan D pembesaran $400 \times$.

A dan B dari ileum mencit non KEP, C dan D dari ileum mencit KEP

hebat dan bermakna (dari 1492 menjadi 145, p = 0,000, Gambar 2).

Pemeriksaan mikroskopis sayatan melintang ileum mencit KEP dengan pengecatan HE tampak ada kerusakan epitel dan atropi vilus. Sel epitel di puncak vilus yang tingkat deferensiasinya tinggi terutama berfungsi menyerap (absorbtif), sedangkan epitel kripta yang tidak berdeferensiasi terutama berfungsi merembih (sekretorik). Karena itu apabila terjadi kerusakan sel epitel usus dan atropi vilus akan mengganggu dan mengurangi fungsi penyerapan, 
terjadi peningkatan: sekresi cairan dan ion di usus, permeabilitas usus terhadap makromolekul dan ion, sehingga berpeluang kehilangan cairan meningkat dan elektrolit yang terkumpul di rongga usus, dan kemudian dikeluarkan melalui gejala diare. ${ }^{11}$ Kerusakan epitel akan menurunkan penunjukan Toll Like Receptors (TLRs) yang merupakan bagian dari kekebalan yang berpembawaan bagus (innate immunity). Apabila penerima ini terpajan mikroorganisme akan memicu respons imun adaptif dengan disekresikannya sitokin pemicu peradangan. Karena itu kekurangan asupan protein dapat menyebabkan defisiensi imun. ${ }^{12}$

Kerusakan epitel usus halus dan defisiensi imun akan berakibat penurunan kandungan PGE2. Hal ini terbukti dengan pemeriksaan teknik imunohistokimiawi yang menunjukkan bahwa di ileum mencit berkondisi KEP terjadi penurunan penunjukan PGE2, yaitu hormon tertentu yang berpengaruh di mekanisme motilitas usus. Motilitas usus merupakan gerakan ritmis usus dalam bentuk kontraksi otot polos. Motilitas usus merupakan bagian innate immunity yang berfungsi sebagai pengendali perlekatan dan perbiakan/pengkolonian mikroorganisme. Motilitas usus akan membantu lapisan mukosa usus untuk mempermudah dan mempercepat pengeluaran antigen keluar dari usus, sehingga dengan adanya motilitas tersebut usus dapat menghambat penyerapan antigen. ${ }^{13}$ Dalam kondisi stres berpotensi sehingga motilitas usus meningkat, yaitu apabila kadar stres ini ditingkatkan seperti kondisi KEP justru usus akan hipomotilitas. ${ }^{14}$ Dalam keadaan tertentu hipermotilitas usus berperan dalam kejadian diare, tetapi hipomotilitas usus tersebut justru lebih jelas berperan dalam kejadian diare. Karena hal tersebut dapat mempermudah periapan (proliferasi) dan perbiakan mikroorganisme di epitel usus, ${ }^{2}$ yang menyebabkan epitel yang terinfeksi mikroorganisme akan mengalami kerusakan.

Dari segi adaptasi intestinal, PGE2 berperan dalam pengaturan proliferasi sel epitel usus, menambah masa mukosa usus dan panjang usus. ${ }^{15}$ Lapisan mukosa usus selalu dalam pembaruan (renewal). Di manusia pergantian epitel usus terjadi setiap 3-6 hari setelah berdeferensiasi menjadi sel yang lebih matang yang mengandung berbagai macam ensim yang berfungsi dalam penyerapan gizi. Perpindahan sel untuk pembaruan berasal dari sel lubang permukaan tonsil (kripta) yang bergerak ke atas dan berakhir di puncak vilus, kemudian sel akan dilepas dan dibuang di rongga usus. PGE2 ikut berpengaruh dalam proses menghasilkan sel dalam kripta. ${ }^{4}$

Dalam kondisi KEP dengan terjadinya penurunan PGE2, selain akan menambah kerusakan epitel usus juga akan menyebabkan berkurangnya adaptasi intestinal, dan terjadi kerusakan epitel dan atropi vilus yang akan bertahan dalam waktu lama sehingga terjadi diare yang berkepanjangan.

\section{SIMPULAN DAN SARAN}

Didasari kajian tersebut di atas dapat disimpulkan bahwa penurunan PGE2 di usus penderita yang kekurangan asupan protein dapat menurunkan motilitas usus dan berpeluang menjadi penyebab angka kematian karena diare meninggi.

Pada penatalaksanaan penderita diare kronis khususnya di penderita defisiensi imun perlu diperhatikan kemungkinan penurunan motilitas usus.

\section{DAFTAR PUSTAKA}

1. DepKes R.I. Pedoman Tata Laksana Kekurangan Enerji Protein pada Anak di Tingkat Rumah Sakit, Buku 1, 2005; 1-10.

2. Roy CC. Diarrheal disorder, $4^{\text {th }}$ Edition, Mosby, St Louis, 1995; 216-227.

3. Kato T, Owen RL. Structure and Function of Intestinal Mucosal Epithelium. In: Mucosal Immunology, $2^{\text {nd }}$ Edition, Edited by Opa DL, San Diego, Academic Press, 1999; 115-132.

4. Ganong WF. Fisiologi Kedokteran, Edisi 22, Jakarta, EGC, 2000; 321-322.

5. Hafez ESE. Reproduction in Farm Animal, $7^{\text {th }}$ Edition, Philadelphia, Lippincott Wiliams \& Wilkins, A Wollers Kluwer Company, 2000; 45-46.

6. Ophard CE. Virtual Chembook, Elmhurst College, 2003.

7. Zhou W, Blackwell TS, Goleniewska K, O'Neal JF, FitzGerald GA, Lucitt M, Breyer RM, Peebles RS. Prostaglandin $\mathrm{I}_{2}$ analogs inhibit Th1 and Th2 effector cytokine production by CD4 T cells, Journal of Leucocyte Biology 2007; (March 81): 809-817.

8. Chandra RK. Nutrition and Immunity: lesson from the past and new insights in the future, American Journal of Clinical Nutrition 1991; 53: 1087-1101.

9. Santos MA, Rosa R, Curi, Barbieri DHGP. Effect of Protein Malnutrition on glycolytic and glutaminolytic enzyme activity of rat thymus and mesenteric lymph nodes, Braz J Med Biol Res 1997; 30 (6): 719-722.

10. Sudiana IK. Teknologi Ilmu Jaringan dan Imunohistokimia, Jakarta, Sagung Seto, 2005; 17-27, 40-49.

11. Lencer WJ. Transport of water and ions. In: Pediatric Gastrointestinal Disease Pathophysiology, Diagnosis Management, Vol 1, $2^{\text {nd }}$ Edition, Edited by Walker WA, Mosby, St Louis, 1996; 97-102.

12. Abbas AK, Lichtman AH, and Pillai S. Cellular and Molecular Immunology, $6^{\text {th }}$ Edition, Saunders Elsever, Philadelphia, 2007, 475-476.

13. Sanderson IR, Walker WA. Intake and Transport of Macromolecules by the Intestine, Gastroenterology, 1993; 13: 622 .

14. Asnar E. Peran Perubahan Limfosit Penghasil Sitokin dan Peptida Motilitas Usus terhadap Modulasi Respons Imun Mukosal Tikus yang Stres akibat Stresor Renjatan Listrik, Disertasi Doktor, Program Pascasarjana Universitas Airlangga, 2001.

15. Vanderhoof JA. Short Bowel Syndrome and Intestinal Adaption. In: Pediatric Gastrointestinal Disease, Pathohysiology, Diagnosis, Management, $3^{\text {rd }}$ Edition, Edited by Walker WA, Durie PR, Hamilton JR, Smith JAW, Watkins JB, Ontario, BC Deckers Inc, 2000; 583-602. 